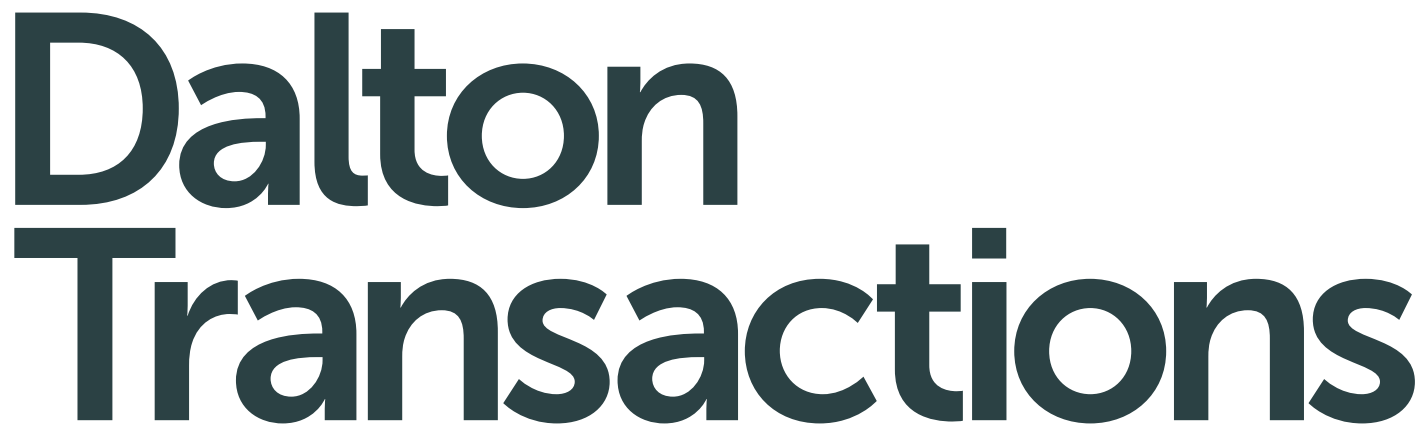

An international journal of inorganic chemistry www.rsc.org/dalton

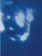

it:y

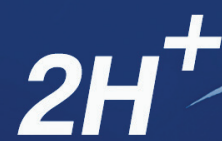
8
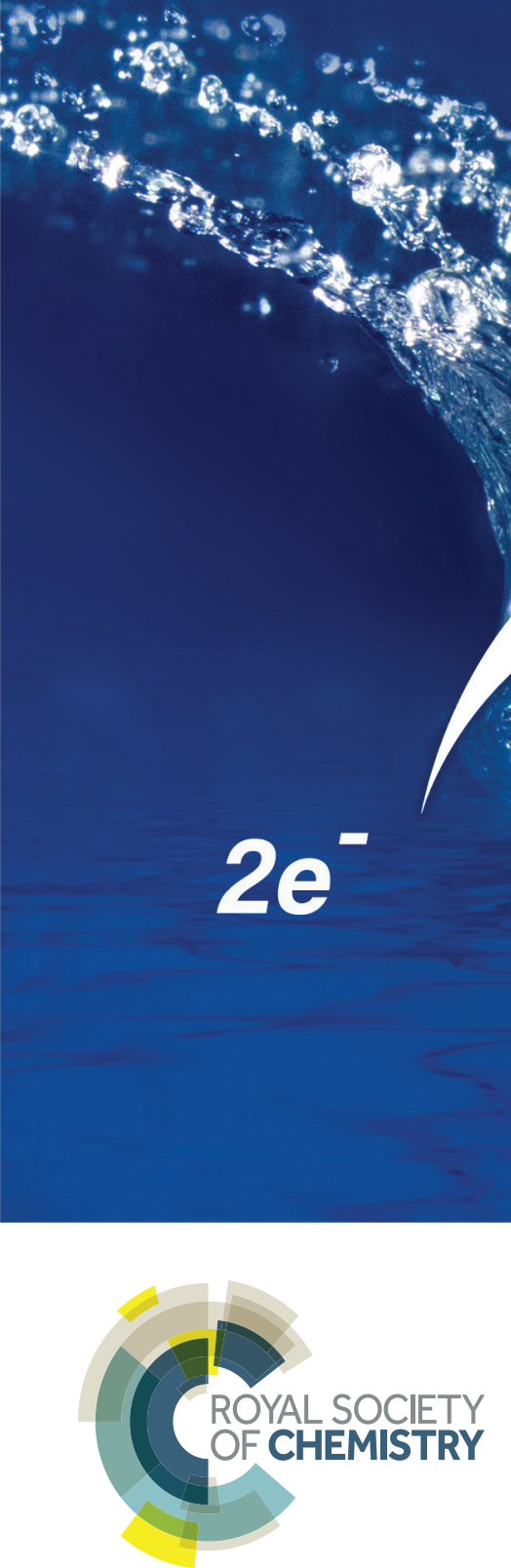

\section{PAPER}

C. Esmieu and G. Berggren

Characterization of a monocyanide model of FeFe hydrogenases highlighting the importance of the bridgehead nitrogen for catalysis
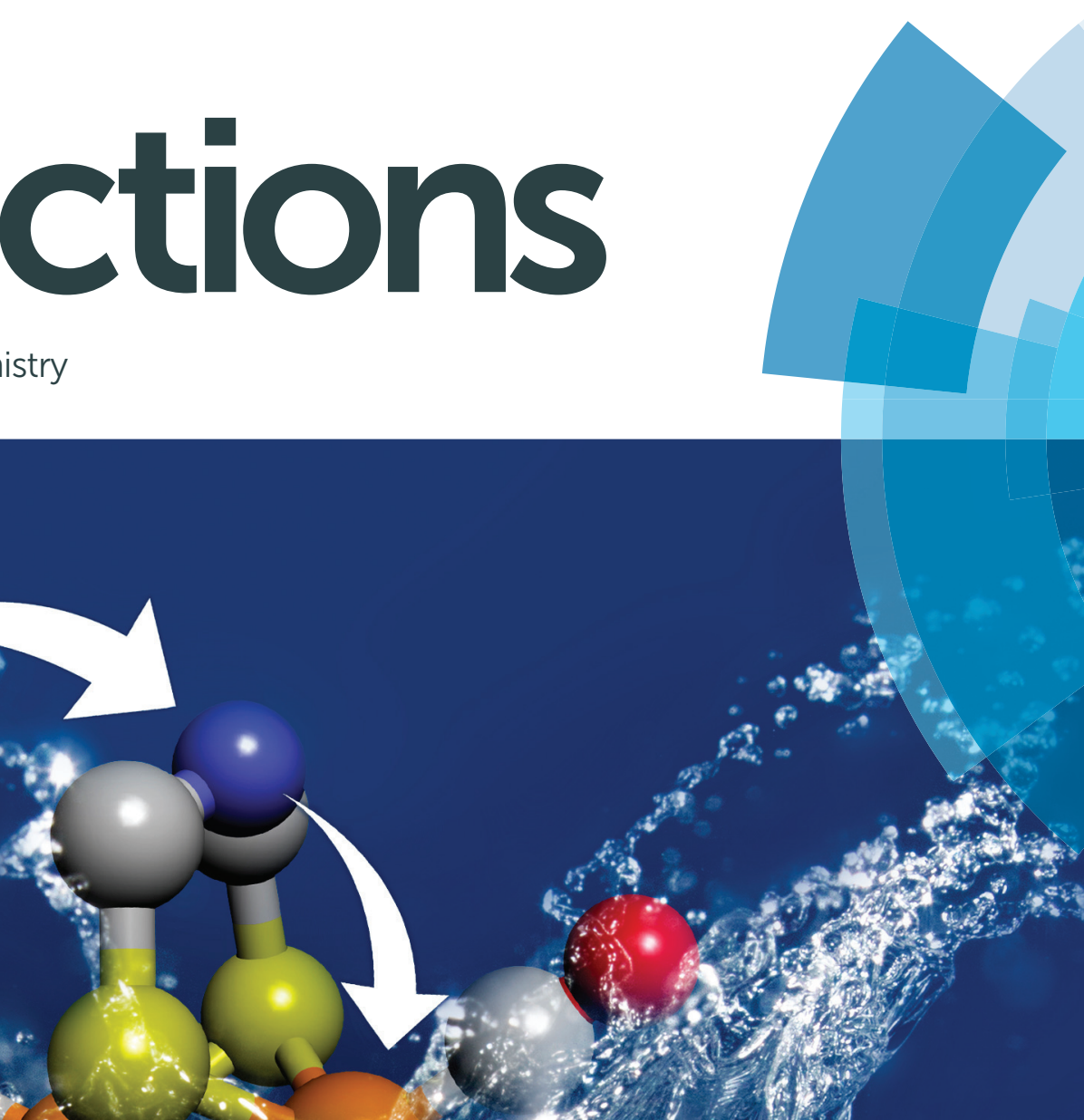

4; $\div 40$
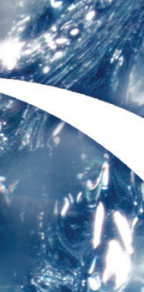

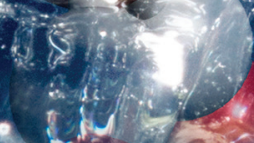
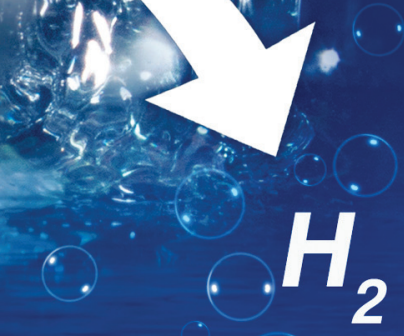


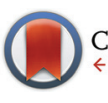

CrossMark \& click for updates

Cite this: Dalton Trans., 2016, 45 19242

Received 23rd May 2016 Accepted 10th August 2016

DOI: $10.1039 / c 6 d t 02061 e$

www.rsc.org/dalton

\title{
Characterization of a monocyanide model of FeFe hydrogenases - highlighting the importance of the bridgehead nitrogen for catalysis $\uparrow$
}

\author{
C. Esmieu and G. Berggren*
}

\begin{abstract}
An azadithiolate bridged monocyanide derivative $\left[\mathrm{Fe}_{2}(\mathrm{adt})(\mathrm{CO})_{5}(\mathrm{CN})\right]^{-}$of $\left[\mathrm{Fe}_{2}(\mathrm{adt})(\mathrm{CO})_{4}(\mathrm{CN})_{2}\right]^{2-}$ has been prepared and extensively characterized as a model of the [FeFe]-hydrogenase active site, using a combination of FTIR spectroscopy, electrochemical methods and catalytic assays with chemical reductants. The presence of two basic nitrogen sites opens up multiple protonation pathways, enabling catalytic proton reduction. To our knowledge $\left[\mathrm{Fe}_{2}(\mathrm{adt})(\mathrm{CO})_{5}(\mathrm{CN})\right]^{-}$represents the first example of a cyanide containing [FeFe]-hydrogenase active site mimic capable of catalytic $\mathrm{H}_{2}$ formation in aqueous media.
\end{abstract}

\section{Introduction}

Hydrogenases are enzymes that catalyze the reversible reduction of protons to molecular hydrogen. In the case of [FeFe]-hydrogenases the reaction occurs at the "H-cluster", which consists of a canonical [4Fe4S]-cluster coupled to a dinuclear iron complex called the $[2 \mathrm{Fe}]$ subsite. The $[2 \mathrm{Fe}]$ subsite features a bridging azadithiolato ligand (adt = $\left[-\mathrm{SCH}_{2} \mathrm{NHCH}_{2} \mathrm{~S}-\right]^{2-}$ ), as well as three $\mathrm{CO}$ and two $\mathrm{CN}^{-}$ligands (Fig. 1). ${ }^{1-4}$ Due to the extreme catalytic efficiency of the

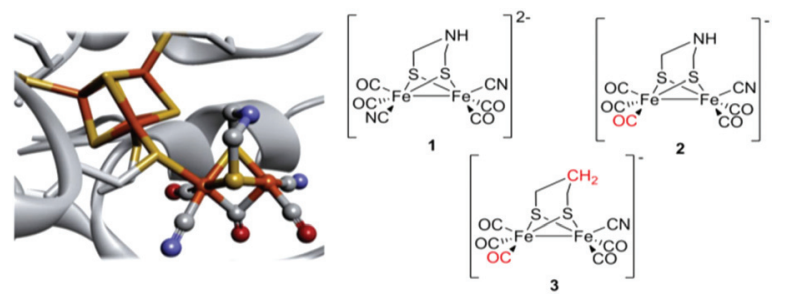

Fig. 1 Schematic representation of the inorganic cofactor constituting the active site of [FeFe]-hydrogenase and the synthetic complexes employed in this study. (Left) The complete $\mathrm{H}$-cluster. Heteroatom color coding: $\mathrm{Fe}=$ orange, $\mathrm{S}=$ yellow, $\mathrm{N}=$ blue, and $\mathrm{O}=$ red; figure generated from Protein Data Bank entry 3C8Y (Clostridium pasteurianum [FeFe]hydrogenase, Cpl, selected amino acids removed to provide an unobstructed view of the cofactor). (Right) The [2Fe] subsite mimics 1, 2 and 3 .

Molecular Biomimetics, Department of Chemistry - Ångström Laboratory, Uppsala University, 75120 Uppsala, Sweden.E-mail: Gustav.berggren@kemi.uu.se

$\dagger$ Electronic supplementary information (ESI) available: Additional data concerning the crystal structure, catalytic assays and electrochemistry experiments. CCDC 1437643 for $2\left[\mathrm{Et}_{4} \mathrm{~N}\right]$. For ESI and crystallographic data in CIF or other electronic format see DOI: 10.1039/c6dt02061e enzyme in combination with the unique nature of the cofactor, the $[2 \mathrm{Fe}]$ subsite has attracted substantial attention from the bioinorganic chemistry community and numerous [FeFe]hydrogenase or $[2 \mathrm{Fe}]$ subsite mimics have been reported.

These complexes generally feature $\mathrm{CO}$ ligands in combination with surrogate ligands, e.g. carbenes, amines or phosphines, which are said to approach the electron donating properties of cyanide. ${ }^{5,6}$ Indeed, the use of the latter ligand outside of a protective protein environment has been proven difficult, and consequently [2Fe] subsite model systems employing the more biomimetic cyanide ligands are still less explored. $^{7-15}$

The new found possibility to artificially activate the [FeFe] hydrogenase enzyme, through the introduction of cyanide ligated synthetic complexes with the general structure $\left[\mathrm{Fe}_{2}(\mathrm{xdt})(\mathrm{CO})_{5-y}(\mathrm{CN})_{1+Y}\right]^{(1+y)-}$ into the apo-enzyme $(Y=0$ or 1 ; xdt denotes different bridging dithiolate ligands), has resulted in a renewed interest in this subclass of [2Fe] subsite mimics. ${ }^{4,16-20}$ The original report on artificial maturation emphasized the importance of the nitrogen bridgehead atom for efficient catalysis. The introduction of $\left[\mathrm{Fe}_{2}(\mathrm{adt})-\right.$ $\left.(\mathrm{CO})_{4}(\mathrm{CN})_{2}\right]^{2-}(\mathbf{1})$ (Fig. 1) resulted in a fully active enzyme indistinguishable from a native [FeFe]-hydrogenase, while the propylene- and dimethylether dithiolate derivatives, $\left[\mathrm{Fe}_{2}(\mathrm{pdt})-\right.$ $\left.(\mathrm{CO})_{4}(\mathrm{CN})_{2}\right]^{2-}$ and $\left[\mathrm{Fe}_{2}(\mathrm{odt})(\mathrm{CO})_{4}(\mathrm{CN})_{2}\right]^{2-}$ generated poorly active "artificial" hydrogenases (pdt $=\left[-\mathrm{SCH}_{2} \mathrm{CH}_{2} \mathrm{CH}_{2} \mathrm{~S}-\right]^{2-}$; odt $\left.=\left[-\mathrm{SCH}_{2} \mathrm{OCH}_{2} \mathrm{~S}^{-}\right]^{2-}\right){ }^{4} \mathrm{~A}$ more extensive study has been recently reported by Siebel $e t$ al., in which 15 different [2Fe] subsite mimics were screened for incorporation into the enzyme in order to better elucidate the structure/activity relationship of the active site. Remarkably, while the cofactor derivatives generally showed only minor residual activity, the monocyanide analogue $\left[\mathrm{Fe}_{2}(\mathrm{adt})(\mathrm{CO})_{5}(\mathrm{CN})\right]^{-}$(2) (Fig. 1) 
retained approximately $50 \%$ activity compared to the native enzyme. ${ }^{18}$ Despite its notable reactivity once introduced into the apo-enzyme, there are no reports about the chemistry of complex 2 in solution. Thus, herein we report its synthesis, structural characterization, protonation behavior and (electro-) catalytic properties, in order to gain further insight into the chemistry of cyanide ligated $[2 \mathrm{Fe}]$ subsite mimics and to facilitate the preparation of new improved cofactors for artificial hydrogenase maturation. Where relevant, we also compare with the dicyanide analogue, $\mathbf{1}$, as well as a form of the complex lacking the nitrogen bridgehead, i.e. $\left[\mathrm{Fe}_{2}(\mathrm{pdt})-\right.$ $\left.(\mathrm{CO})_{5}(\mathrm{CN})\right]^{-}(3)$, in order to elucidate the potential similarities and key differences.

\section{Experimental}

Chemicals were purchased from Aldrich Chemicals and used without further purification unless noted otherwise.

All manipulations were performed using standard Schlenk and vacuum-line techniques under dinitrogen $\left(\mathrm{N}_{2}\right)$ or in an Ar-filled glovebox. $\mathrm{CH}_{3} \mathrm{CN}$ was distilled under $\mathrm{N}_{2}$ from $\mathrm{CaH}_{2}$, whereas $\mathrm{Et}_{2} \mathrm{O}$ and THF were distilled under $\mathrm{N}_{2}$ from sodium/ benzophenone ketyl. Heptane was used without previous distillation. $\left[\mathrm{Fe}_{2}(\mathrm{adt})(\mathrm{CO})_{6}\right], \mathbf{1}$ and $\mathbf{3}$ were synthesized according to the literature procedures, while complex 2 was synthesized via a modified literature protocol. ${ }^{5,8,14,18}$ Elemental analysis (C, $\mathrm{H}$ and $\mathrm{N}$ ) was performed by Analytische Laboratorien GmbH, Industriepark Kaiserau, D-51789 Lindlar, Germany.

\section{Synthesis of $\left[\mathrm{Fe}_{2}(\mathbf{a d t})(\mathrm{CO})_{5}(\mathrm{CN})\right]\left[\mathrm{Et}_{4} \mathrm{~N}\right], 2\left[\mathrm{Et}_{4} \mathrm{~N}\right]$}

$\left[\mathrm{Fe}_{2}(\mathrm{adt})(\mathrm{CO})_{6}\right](0.025 \mathrm{~g}, 0.065 \mathrm{mmol})$ was dissolved in $\mathrm{CH}_{3} \mathrm{CN}$ $(2 \mathrm{ml})$ and $\mathrm{Me}_{3} \mathrm{NO}(0.0072 \mathrm{~g}, 0.065 \mathrm{mmol})$ was added as a solid. The solution was then cooled to $-40{ }^{\circ} \mathrm{C}$ and treated via a cannula with a solution of $\left[\mathrm{Et}_{4} \mathrm{~N}\right][\mathrm{CN}](0.0096 \mathrm{~g}, 0.061 \mathrm{mmol})$ in $\mathrm{CH}_{3} \mathrm{CN}(3 \mathrm{ml})$. The reaction mixture was allowed to warm up to room temperature and was stirred for $2 \mathrm{~h}$. The solvent was removed under reduced pressure to give a dark red residue; this was dissolved in THF (5 mL) and filtered via a cannula to give a dark red filtrate. The solution was concentrated (to $1 \mathrm{~mL}$ ), precipitated with heptane $(10 \mathrm{~mL})$ and the residue was washed with $15 \mathrm{~mL} \mathrm{Et}_{2} \mathrm{O}$. The product was isolated as a highly hygroscopic black/red solid $(0.026 \mathrm{~g}, 76 \%)$ and verified by FTIR, $\nu_{\max } / \mathrm{cm}^{-1}$ (DMSO) 2091, 2028, 1970, 1953, 1939, and 1911. Anal. Calcd for $\mathrm{C}_{16} \mathrm{H}_{32} \mathrm{Fe}_{2} \mathrm{~N}_{3} \mathrm{O}_{8.5} \mathrm{~S}_{2}\left(2\left[\mathbf{E t}_{4} \mathbf{N}\right] \cdot 3.5 \mathrm{H}_{2} \mathrm{O}\right.$, $580.27 \mathrm{~g} \mathrm{~mol}^{-1}$ ): C, 33.23; H, 5.58; N, 7.27; Found: C, 33.3; H, 5.61; N, 7.32.

\section{X-ray diffraction}

All the measurements were performed using graphite-monochromatized Mo $\mathrm{K}_{\alpha}$ radiation at $100 \mathrm{~K}$ using a Bruker D8 APEX-II equipped with a CCD camera. The structure was solved by direct methods (SHELXS-2014) and refined by fullmatrix least-squares techniques against $F^{2}$ (SHELXL-2014/7). ${ }^{21}$ The non-hydrogen atoms were refined with anisotropic displacement parameters. The $\mathrm{H}$ atoms of the $\mathrm{CH}_{2}$ groups were refined with common isotropic displacement parameters for the $\mathrm{H}$ atoms of the same group and idealized geometry with approximately tetrahedral angles and $\mathrm{C}-\mathrm{H}$ distances of $0.99 \AA$. The $\mathrm{H}$ atom of the amine was refined to idealized geometry. The tetraethylammonium unit shows a disorder of all ethyl chains, which are modeled by a positional disorder (sof = 0.73131). A partial disorder of the $\mathrm{CN}^{-}$group over other basal positions cannot be ultimately excluded from the crystallographic data. CCDC 1437643 contains the supplementary crystallographic data for this paper.

\section{FTIR spectroscopy}

FTIR absorption spectra of 2 were recorded in the spectral range of $2150-1800 \mathrm{~cm}^{-1}$ with a resolution of $2 \mathrm{~cm}^{-1}$ on a Perkin Elmer SpectrumOne FTIR spectrometer. The IR measurements were performed with a liquid-sample-cell (Specac Omni-Cell) using $\mathrm{CaF}_{2}$ windows with $0.5 \mathrm{~mm}$ PTFE spacers in $\mathrm{CH}_{3} \mathrm{CN}$, DSMO, THF or DMSO/ $\mathrm{H}_{2} \mathrm{O}(1: 1)$.

\section{Catalytic assays with europium(II) salts}

The preparation was done in a glovebox under a wet $\mathrm{N}_{2}$ atmosphere at room temperature in $8 \mathrm{~mL}$ sealed vials. The complexes, $\mathbf{1}$ or 2 , (final conc.: $0.25 \mathrm{mM}$ ) were dissolved in a mixed HEPES (50 mM, pH 7.5) and DMSO (1:1) buffer. The glass vials were then sealed with rubber septa inside the glovebox. The reductants [Eu-DTPA] ${ }^{2-}$ and [Eu-EGTA $]^{2-}(25 \mathrm{mM})$ were prepared in situ by injection of stock solutions $(400 \mathrm{mM}$, in $50 \mathrm{mM}$ HEPES, pH 7.5) of first $\mathrm{EuCl}_{2}$ followed by either DTPA or EGTA. The evolution of hydrogen was monitored by injecting $250 \mu \mathrm{L}$ of the headspace gas into a gas chromatograph (GC).

\section{Electrochemistry}

Electrochemistry experiments were performed in the glovebox using a one-compartment, three-electrode configuration connected to an Autolab PGSTAT100 potentiostat controlled using GPES 4.9 software (EcoChemie). The electrode setup included a glassy carbon disc $\left(0.0701 \mathrm{~cm}^{2}\right.$ or $0.22 \mathrm{~cm}^{2}$ for cyclic voltammetry and bulk electrolysis experiments) working electrode that was polished using $0.05 \mu \mathrm{m}$ alumina prior to use, a carbon rod auxiliary electrode, and a $\mathrm{Ag} / \mathrm{Ag}^{+}$non-aqueous reference electrode $\left(0.01 \mathrm{M} \mathrm{AgNO}_{3}\right.$ in $\mathrm{CH}_{3} \mathrm{CN},-0.094 \mathrm{~V}$ vs. $\mathrm{Fc}^{+/ 0}$; $\left.\mathrm{Fc}=\left[\mathrm{Fe}\left(\mathrm{C}_{5} \mathrm{H}_{5}\right)_{2}\right]\right) . \mathrm{Fc}$ was added as an internal reference at the end of each experiment, and all reported potentials in $\mathrm{CH}_{3} \mathrm{CN}$ are quoted versus the $\mathrm{Fc}^{+/ 0}$ couple. All measurements were conducted with freshly distilled and dry $\mathrm{CH}_{3} \mathrm{CN}$ with tetrabutylammonium hexafluorophosphate $\left(\mathrm{Bu}_{4} \mathrm{NPF}_{6}\right.$, Fluka, electrochemical grade) as the supporting electrolyte $(0.1 \mathrm{M})$. Cyclic voltammograms were recorded at a scan rate of $100 \mathrm{mV} \mathrm{s}^{-1}$ (unless otherwise specified).

\section{Hydrogen measurements by GC}

The hydrogen content was determined using a gas chromatograph (PerkinElmer LLC) equipped with a thermal conductivity detector (TCD) and a stainless-steel column packed with molecular sieves (60/80 mesh). The operational temperatures of the injection port, the oven and the detector were $100{ }^{\circ} \mathrm{C}, 80^{\circ} \mathrm{C}$ 
and $100{ }^{\circ} \mathrm{C}$, respectively. Nitrogen was used as the carrier gas

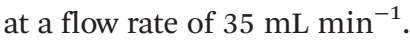

\section{Results and discussion}

\section{Synthesis and structure}

Both complexes $\mathbf{1}$ and $\mathbf{2}$ were synthesized from the corresponding hexacarbonyl compound $\left[\mathrm{Fe}_{2}(\mathrm{adt})(\mathrm{CO})_{6}\right]$ using standard procedures. ${ }^{14,18}$ In the case of the monosubstituted derivative 2 slight modifications to the published protocol were made. Decarbonylation by $\mathrm{Me}_{3} \mathrm{NO}$ followed by the addition of a substoichiometric amount of $\left[\mathrm{Et}_{4} \mathrm{~N}\right][\mathrm{CN}]$ allowed the isolation of the desired product with good yield (76\%).

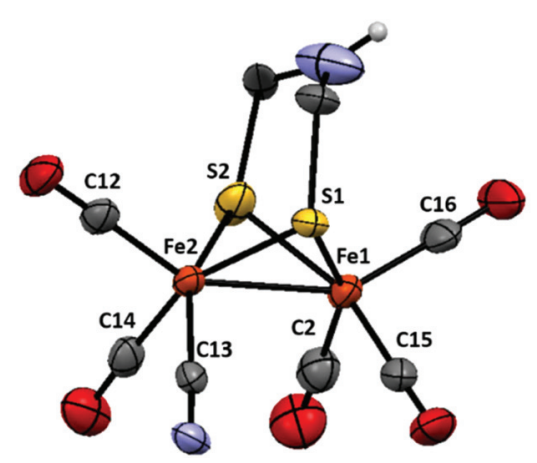

Fig. 2 Structure of the anion in $\left(\mathrm{Et}_{4} \mathrm{~N}\right) 2,\left[\mathrm{Fe}_{2}(\mathrm{adt})(\mathrm{CO})_{5}(\mathrm{CN})\right]^{-}$, with the thermal ellipsoids set at the $50 \%$ probability level. Selected distances ( $\AA$ ) and angles ( $\left(^{\circ}\right)$ : Fe1-Fe2, 2.5076(7); Fe1-S1, 2.2684(11); Fe1-S2, 2.265(11); $\mathrm{Fe} 1-\mathrm{C} 2,1.773(5) ; \mathrm{Fe} 1-\mathrm{C} 16,1.787(4) ; \mathrm{Fe} 1-\mathrm{C} 15,1.780(4) ; \mathrm{Fe} 2-\mathrm{S} 1,2.2481(11)$; $\mathrm{Fe} 2-\mathrm{S} 2,2.2383(11) ; \mathrm{Fe} 2-\mathrm{C} 13(\mathrm{~N}), 1.917(4) ; \mathrm{Fe} 2-\mathrm{C} 14,1.753(4) ; \mathrm{Fe} 2-\mathrm{C} 12$, 1.775(4); S1-Fe1-S2, 84.56(4) ${ }^{\circ}$; S1-Fe2-S2, 85.66(4) ${ }^{\circ}$.

The structure of 2 was confirmed by single-crystal X-ray diffraction (Fig. 2). Single crystals suitable for X-ray diffraction experiments were grown upon layering heptane onto a THF solution of 2 , under anaerobic conditions and at room temperature. The structure shows the usual distorted square-pyramidal geometry around the iron center. The cyanide ligand is coordinated to an equatorial site on $\mathrm{Fe}(2)$ and roughly cis to the $\mathrm{Fe}-\mathrm{Fe}$ bond. It follows that complex 2 adopts the same type of solid-state structure as that of its pdt analogue, 3, reported by Rauchfuss and co-workers. ${ }^{8}$ The Fe-Fe distance is slightly shorter in the case of the adt complexes, $2.507 \AA$ in 2 vs. $2.529 \AA$ in 3 , and more comparable to what is observed for the dicyanide complex 1 (2.509 $\AA$ ). Conversely, the $\operatorname{Fe}(2)-S(1,2)$ bonds are significantly shorter in both 2 and 3 compared to the distances found in 1 (average distances: 2.243, 2.252 and $2.283 \AA$ A respectively).

\section{FTIR spectroscopy}

The FTIR spectrum of complex 2 in the polar solvent DMSO, is in agreement with the reported data and shows five absorption bands in the range of $1900-2030 \mathrm{~cm}^{-1}$ for its terminal carbonyls and one band around $2100 \mathrm{~cm}^{-1}$ for the cyanide ligand

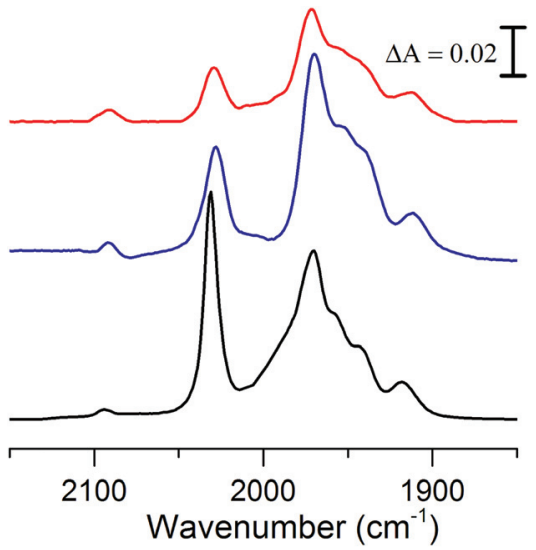

Fig. 3 Absorbance FTIR spectra of 2: DMSO solution (black), THF solution (blue) and DMSO/ $\mathrm{H}_{2} \mathrm{O}(1: 1)$ solution (red).

(Fig. 3, black line). ${ }^{18}$ The shoulder observed at $1987 \mathrm{~cm}^{-1}$ in DMSO appears to be solvent dependent, as it is not observable in the non-polar solvent THF (Fig. 3, blue line), in line with what has been observed for complex $3 .^{8}$ Because of our interest for 2 in a biological context the influence of water on the spectrum and stability was studied. The poor solubility of 2 in water did not allow us to perform FTIR measurement in pure aqueous media and instead a solution of $\mathrm{DMSO} / \mathrm{H}_{2} \mathrm{O}(1: 1)$ was used (Fig. 3, red line). The FTIR spectrum of 2 under these conditions is similar to what is observed in pure DMSO, although the complex slowly decomposes in the presence of water with about $65 \%$ remaining after $2 \mathrm{~h}$ (ESI Fig. S1†).

\section{Catalytic assay}

The capacity of 2 for catalytic $\mathrm{H}_{2}$ evolution from mixed DMSO/ $\mathrm{H}_{2} \mathrm{O}$ (1:1) solutions buffered at $\mathrm{pH} 7.5$ with HEPES was assayed using reduced methyl viologen (MV) $\left(E^{\circ}=-0.446 \mathrm{~V} v s\right.$. $\mathrm{SHE})$ as well as europium based reductants $\left(E^{\circ}=-0.88\right.$ to $-1.14 \mathrm{~V} v s$. SHE). The amount of $\mathrm{H}_{2}$ gas produced was monitored by gas chromatography (GC), via sampling of the headspace gas.

No activity could be observed when 2 (0.5 mM) was assessed under classical enzymatic assay conditions, with sodium dithionite $(0.1 \mathrm{M})$ and methyl viologen $(0.01 \mathrm{M}) .^{22}$ Conversely, efficient $\mathrm{H}_{2}$ evolution was detected when a more reducing europium complex was employed. The europium(II) ion is a relatively weak reductant, but can generate more potent one-electron reductants upon mixing with equimolar amounts of polyaminocarboxylate ligands. ${ }^{23,24}$

Two ligands were employed for the complexation with $\mathrm{Eu}^{\mathrm{III} / \mathrm{II}}$ : EGTA (ethylene glycol-bis(2-aminoethylether)- $N, N, N^{\prime}, N^{\prime}$-tetraacetic acid) and DTPA (diethylenetriamine- $N, N, N^{\prime}, N^{\prime \prime}, N^{\prime \prime}$-pentaacetic acid), and the resulting complexes are denoted as EuEGTA and Eu-DTPA. At pH 8.0, the standard reduction potentials $\left(E_{(\mathrm{Eu}(\mathrm{III}) / \mathrm{Eu}(\mathrm{II}))}^{\circ}\right)$ of the $\mathrm{Eu}^{\mathrm{III} / \mathrm{II}}$-EGTA and $\mathrm{Eu}^{\mathrm{III} / \mathrm{II}}$-DTPA couples are $-0.88 \mathrm{~V}$ and $-1.14 \mathrm{~V}$ (vs. SHE). ${ }^{23}$

The hydrogen evolution capacity of complexes 1 and 2 was studied by the addition of a hundredfold excess of Eu-EGTA or Eu-DTPA, relative to the catalyst, to the catalytic assays (Fig. 4). 


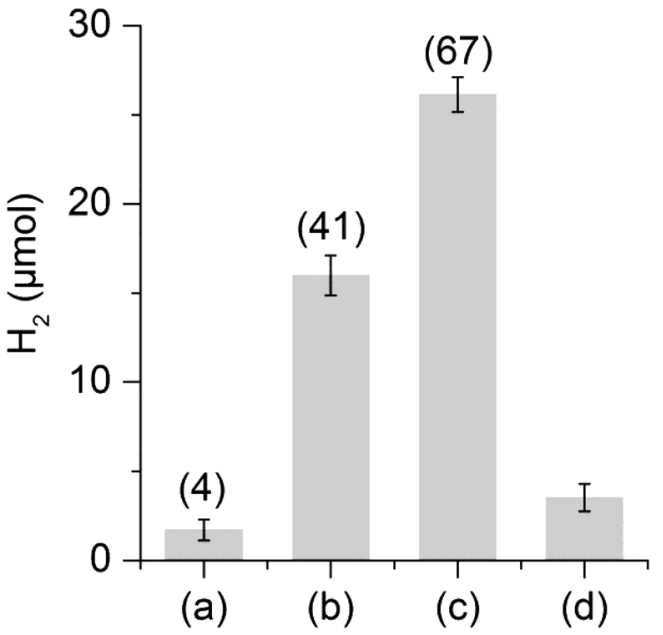

Fig. $4 \mathrm{H}_{2}$ production after $10 \mathrm{~min}$ of reaction in the presence of EuDTPA $(39 \mu \mathrm{mol}, 25 \mu \mathrm{mM})$. (a) Complex $1(0.39 \mu \mathrm{mol}, 0.25 \mu \mathrm{mM})$; (b) complex $2(0.39 \mu \mathrm{mol}, 0.25 \mathrm{mM})$; (c) complex $2(0.39 \mu \mathrm{mol}, 0.25 \mathrm{mM})$ with total $\mathrm{H}_{2}$ production following a second addition of Eu-DTPA; (d) blank. Total turnover numbers are reported in parentheses. All reactions were performed in DMSO/ $\mathrm{H}_{2} \mathrm{O}(1: 1)$ buffer $(50 \mathrm{mM}$ HEPES, pH 7.5), $V=$ $1.5 \mathrm{~mL}$, at $25^{\circ} \mathrm{C}$.

In the case of Eu-DTPA we observed a slow spontaneous decomposition of the reductant under our buffer conditions resulting in a small amount of $\mathrm{H}_{2}$, up to $2 \mu \mathrm{mol}$ without addition of a catalyst. However, the presence of $2(0.25 \mathrm{mM})$ resulted in significantly higher $\mathrm{H}_{2}$ production corresponding to 41 turnovers (TON) $(16 \mu \mathrm{mol} \pm 7 \%)$ already after 10 minutes; extending the reaction time results in a marginal increase of $\mathrm{H}_{2}$ production (see ESI Fig. S2 $\dagger$ ). The formation of $\mathrm{H}_{2}$ via proton reduction is a two electron process giving a maximum TON of 50 , and consequently a yield of $82 \%$ for $\mathrm{Eu}(\mathrm{II})$ to $\mathrm{H}_{2}$. Addition of another 100 eq. of Eu-DTPA to the assay after one hour allowed us to restart the reaction, albeit with slightly lower yield (54\%), supporting the stability of 2 under catalytic conditions (Fig. 4). In contrast, no $\mathrm{H}_{2}$ generation could be observed with 1 . The difference in reactivity between 1 and 2 can be attributed to the possible instability of $\mathbf{1}$ under the assay conditions or, more likely, the difference in the redox potential existing between the two complexes (see below). Under the same conditions, no $\mathrm{H}_{2}$ production was observed with Eu-EGTA with either complexes, indicating that the reduction potential required for efficient catalysis lies between -0.9 and $-1.14 \mathrm{~V}$ (vs. SHE). Finally, changing the buffer for a Tris buffer does not affect the activity of compound 2 (see ESI Fig. S2 $\dagger$ ). To the best of our knowledge complex 2 represents the first cyanide containing [2Fe] subsite mimic to exhibit catalytic $\mathrm{H}_{2}$ production in aqueous media using chemical reductants.

\section{FTIR spectroscopy after protonation}

In light of the catalytic properties of complex 2 the protonation behavior of the complex was studied, a key issue to start addressing the catalytic mechanism. Complex 2 features three

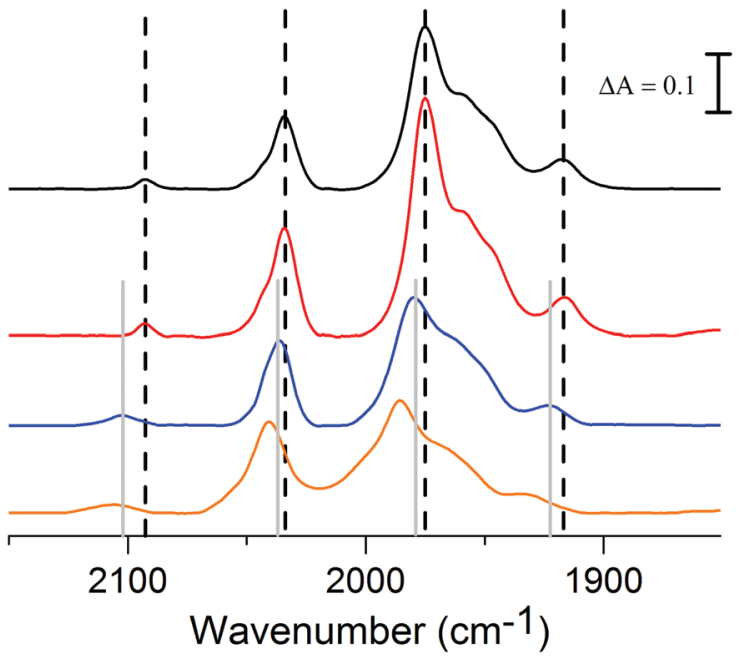

Fig. 5 The influence of acids on the absorbance FTIR spectrum of 2 (0.25 mM) in $\mathrm{CH}_{3} \mathrm{CN}$. 2 in pure $\mathrm{CH}_{3} \mathrm{CN}$ (black); 2 in the presence of $\mathrm{AcOH}(2.5 \mathrm{mM}$, red); 2 in the presence of $\mathrm{AcOH}(250 \mathrm{mM}$, blue); 2 in the presence of $\mathrm{Cl}_{2} \mathrm{CHCOOH}$ (2.5 mM, orange). Dashed vertical lines indicate peak positions observed in pure $\mathrm{CH}_{3} \mathrm{CN}$ and grey solid vertical lines indicate peak positions observed in the presence of $250 \mathrm{mM} \mathrm{AcOH}$.

potential sites for protonation, the Fe-Fe bond, the bridgehead nitrogen or the cyanide ligand, all of which are readily distinguishable by FTIR spectroscopy. Interestingly two of these sites could be selectively protonated using acids with different $\mathrm{p} K_{\mathrm{a}}$ values in $\mathrm{CH}_{3} \mathrm{CN}$ solution, i.e. acetic acid, $\mathrm{AcOH}\left(\mathrm{p} K_{\mathrm{a}} \approx\right.$ $22.3)$ or dichloroacetic acid, $\mathrm{Cl}_{2} \mathrm{CHCOOH}\left(\mathrm{p} K_{\mathrm{a}} \approx 16.4\right) .{ }^{25,26}$ The addition of 10 eq. of $\mathrm{Cl}_{2} \mathrm{CHCOOH}$ to an $\mathrm{CH}_{3} \mathrm{CN}$ solution of 2 resulted in a shift of $+16 \mathrm{~cm}^{-1}$ of both the $\mathrm{CO}$ and $\mathrm{CN}^{-}$bands (Fig. 5, orange line), a shift attributable to protonation of the bridgehead nitrogen to generate $\left[\mathrm{Fe}_{2}(\mathrm{Hadt})(\mathrm{CO})_{5}(\mathrm{CN})\right]^{ \pm 0} \cdot{ }^{13}$ Conversely, the addition of 10 eq. of the weaker acid, $\mathrm{AcOH}$, did not result in a detectable shift (Fig. 5, red line). However, after the addition of 40 eq. of AcOH a new species started to appear in the spectrum, and complete conversion was obtained after the addition of 1000 eq. of AcOH (Fig. 5, blue line). In this case the $\mathrm{CO}$ and $\mathrm{CN}^{-}$bands have been shifted by approximately $10 \mathrm{~cm}^{-1}$ towards higher frequencies; this smaller shift indicates protonation of the cyanide ligand generating $\left[\mathrm{Fe}_{2}(\mathrm{adt})(\mathrm{CO})_{5}(\mathrm{CNH})\right]^{ \pm 0}$ and has previously been reported for $\left[\mathrm{HFe}_{2}(\mathrm{pdt})(\mathrm{CO})_{4}\left(\mathrm{PMe}_{3}\right)(\mathrm{CNH})\right]^{+1} \cdot{ }^{10}$ Moreover, no hydride formation could be observed under these conditions, in agreement with the literature data for the pdt analogue $3 .^{8}$

\section{Electrochemistry}

Electrochemical characterization of 2 by cyclic voltammetry was performed in an $\mathrm{CH}_{3} \mathrm{CN}$ electrolyte. The cyclic voltammogram (CV) of the complex displayed one irreversible oxidation peak $\left(i_{\mathrm{p}}, \mathrm{a}\right)$ at $-0.043 \mathrm{~V}$ and one irreversible reduction peak $\left(i_{\mathrm{p}, \mathrm{c}}\right)$ at $-2.23 \mathrm{~V}$, versus $\mathrm{Fc}^{+/ 0}$ (Fig. 6). These two processes are diffusion-limited, as indicated by the linear dependence of the peak current on the square root of the scan rate (ESI Fig. S3 $\dagger$ ). Moreover, increasing the scan rate up to $1000 \mathrm{mV} \mathrm{s}^{-1}$ does not 


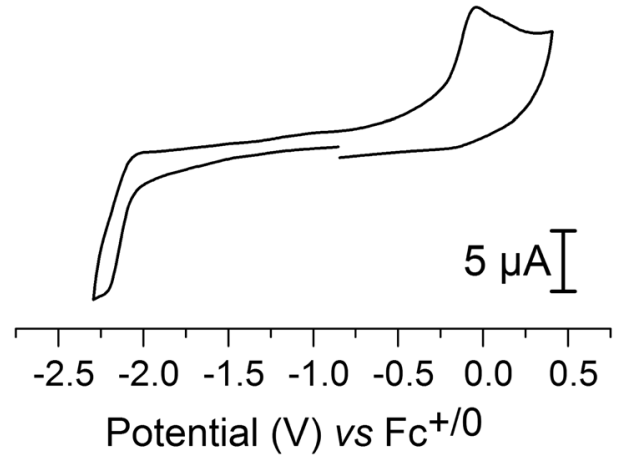

Fig. 6 Cyclic voltammogram of $2(200 \mu \mathrm{M})$ recorded in $\mathrm{CH}_{3} \mathrm{CN}$. Electrolyte: $\mathrm{Bu}_{4} \mathrm{NPF}_{6}(0.1 \mathrm{M})$; scan rate $=100 \mathrm{mV} \mathrm{s}{ }^{-1}$; recorded at $20{ }^{\circ} \mathrm{C}$ using a glassy carbon disc as a working electrode with a surface area of $0.0701 \mathrm{~cm}^{2}$.

allow partial reversibility to be observed, indicating that rapid chemical reactions occur upon both reduction and oxidation.

Based on comparison with the electrochemical data reported for the pdt analogue $3\left(i_{\mathrm{p}, \mathrm{a}}=0.14 \mathrm{~V}, i_{\mathrm{p}, \mathrm{c}}=-2.16 \mathrm{~V}\right.$ versus $\mathrm{Fc}^{+/ 0}$ ) the peaks are attributed to metal centered redox reactions (see ref. 8 and ESI Fig. S4†). However, for 3 the oxidation has been argued to be a two-electron process, based on an observed $i_{\mathrm{p}, \mathrm{c}} i_{\mathrm{p}}$, a ratio of $0.5 .^{8}$ In the case of 2 the corresponding ratio is $\approx 1$, and thus we tentatively assign the oxidation peak to a $\mathrm{Fe}^{\mathrm{I}} \mathrm{Fe}^{\mathrm{I}} / \mathrm{Fe}^{\mathrm{II}} \mathrm{Fe}^{\mathrm{I}}$ process, and the reduction peak to a $\mathrm{Fe}^{\mathrm{I}} \mathrm{Fe}^{\mathrm{I}} / \mathrm{Fe}^{0} \mathrm{Fe}^{\mathrm{I}}$ process, respectively.

The effect of cyanide ligation on the redox properties of [2Fe] subsite models has previously been reported for the pdt bridged series $\left[\mathrm{Fe}_{2}(\mathrm{pdt})(\mathrm{CO})_{6}\right], \quad\left[\mathrm{Fe}_{2}(\mathrm{pdt})(\mathrm{CO})_{5}(\mathrm{CN})\right]^{-}$and $\left[\mathrm{Fe}_{2}(\mathrm{pdt})(\mathrm{CO})_{4}(\mathrm{CN})_{2}\right]^{2-}$, where each successive $\mathrm{CO}$ to $\mathrm{CN}^{-}$substitution shifts the reduction potentials by approximately $0.6 \mathrm{~V}$ towards more cathodic potentials. ${ }^{8}$ We observe a similar trend also for the adt bridged analogues, and with respect to $\left[\mathrm{Fe}_{2}(\mathrm{adt})(\mathrm{CO})_{6}\right]$ the oxidation and reduction of 2 occur at potentials that are shifted $0.63 \mathrm{~V}$ and $0.65 \mathrm{~V}$ towards more cathodic potentials, respectively. ${ }^{27}$ An additional shift of $600 \mathrm{mV}$ is observed for the oxidation of the dicyanide derivative, $\mathbf{1}$, compared to 2. The oxidation peak occurs at $-0.62 \mathrm{~V}$ versus $\mathrm{Fc}^{+/ 0}$. The reduction peak is not reachable under our experimental conditions in the case $\mathbf{1}$, and thus shifted by at least $400 \mathrm{mV}$ $\left(E_{\text {red }}<-2.6\right.$ V, ESI Fig. S5 $\left.\dagger\right)$.

In view of the catalytic activity observed for 2 in aqueous media we also explored its electrocatalytic properties. Indeed, cyclic voltammetry studies in the presence of acids revealed that 2 is a competent electrocatalyst for proton reduction. The addition of $2 \mathrm{mM}$ of $\mathrm{AcOH}$ (40 eq.), conditions which result in the formation of $\left[\mathrm{Fe}_{2}(\mathrm{adt})(\mathrm{CO})_{5}(\mathrm{CNH})\right]^{ \pm 0}$ (see above), gave rise to a new reduction peak at $-2.0 \mathrm{~V}$ versus $\mathrm{Fc}^{+/ 0}$. Further addition of acid resulted in an increased current peak height, as expected for an electrocatalytic process (Fig. 7, top, and ESI Fig. S6 $\dagger$ ). This observation is unexpected considering that the pdt analogue 3 is reported to be catalytically inactive, despite very similar redox properties and protonation behavior, i.e.
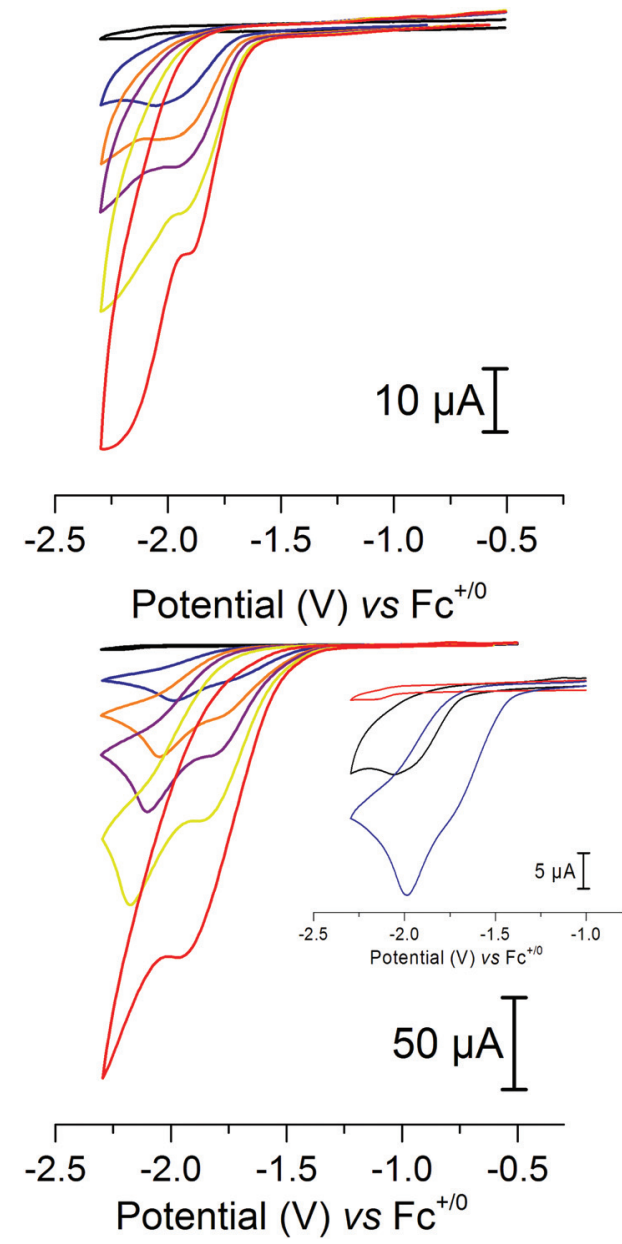

Fig. 7 Cyclic voltammograms of 2 in the presence of increasing amounts of acids (black $=0$ eq., blue $=40$ eq., orange $=80$ eq., violet $=$ 120 eq., yellow $=200$ eq., red $=400$ eq.). (Top) Acetic acid; (bottom) dichloroacetic acid; inset: comparison of 40 eq. of acid, acetic acid (black) and dichloroacetic acid (blue). Conditions: $50 \mu \mathrm{M}$ of 2 in $\mathrm{CH}_{3} \mathrm{CN}$; electrolyte: $\mathrm{Bu}_{4} \mathrm{NPF}_{6}(0.1 \mathrm{M})$; scan rate $=100 \mathrm{mV} \mathrm{s}^{-1}$; glassy carbon as a working electrode with a surface area of $0.0701 \mathrm{~cm}^{2}$.

protonation of the cyanide ligand. ${ }^{10}$ In order to verify that this is not due to differences in the experimental conditions, e.g. choice of acid, we assayed complex 3 under our conditions, but no indication of catalysis was detected (ESI Fig. S4†). We attribute this discrepancy to the presence of the azadithiolate bridge in 2 , which is likely to act as an additional base in the proton reduction mechanism.

The importance of the bridgehead nitrogen is further supported by the electrocatalytic behavior in the presence of $\mathrm{Cl}_{2} \mathrm{CHCOOH}$, an acid shown to favor protonation of the bridgehead nitrogen over the cyanide. Also in the case of $\mathrm{Cl}_{2} \mathrm{CHCOOH}$ the catalytic process at $-2.0 \mathrm{~V}$ is clearly visible in the CV. Moreover, it is preceded by a new catalytic process that appears at $-1.7 \mathrm{~V} v$ s. $\mathrm{Fc}^{+/ 0}$, i.e. $\sim 300 \mathrm{mV}$ more positive, readily distinguishable at lower acid concentrations (Fig. 7, bottom and inset). Again, the current is proportional to the amount of the acid that is added into the solution and higher currents 
are obtained compared to $\mathrm{AcOH}$ with equimolar amounts of the acid (ESI Fig. S7 $\dagger$ ). Currents obtained are also dependent on the concentration of 2 in the solution, and the catalytic wave shows a linear dependence of the peak current on the square root of the scan rate (ESI Fig. S8-S11†), indicating a homogeneous catalytic process.

In contrast, no catalytic activity was observed with 1 under identical conditions, as expected from the catalytic assays described above and CV studies.

The stability of 2 under electrocatalytic conditions was studied by controlled potential coulometry in combination with FTIR spectroscopy, where a solution of 2 was electrolyzed at $-1.7 \mathrm{~V}$ in the presence of excess $\mathrm{Cl}_{2} \mathrm{CHCOOH}$. The production of $\mathrm{H}_{2}$ gas was verified by GC and a total TON of $\approx 15$ was estimated based on the amount of charge passed through the system, before catalysis was stopped after about $1 \mathrm{~h}$ (ESI Fig. S12†). FTIR spectra recorded during the reaction showed that approximately $40 \%$ of complex 2 remained after $1 \mathrm{~h}$. Moreover, a new peak appeared at $2069 \mathrm{~cm}^{-1}$ that increased in intensity during the first $30 \mathrm{~min}$ of the reaction before disappearing (ESI Fig. S13†). This behavior is not attributable to an intrinsic instability of the complex, as 2 remained stable in acetonitrile over the course of $2 \mathrm{~h}$ (ESI Fig. $\mathrm{S} 1 \dagger)$. In the case of $\mathrm{AcOH}$ electrolysis at $-1.8 \mathrm{~V}$ revealed a similar, albeit slower electrocatalytic behavior (ESI Fig. S14†).

\section{Conclusions}

We have reported an in-depth characterization of the monocyanide analogue of the [2Fe] subsite. This subfamily of [2Fe] subsite mimics, featuring one or more cyanide ligands, has received renewed interest as it has been shown that they can be introduced into the active site of [FeFe]-hydrogenases to generate "artificial" or "semi-synthetic" enzymes.

In summary, the basic structural and spectroscopic properties of complex 2 are strikingly similar to those of the pdt bridged complex 3. Still, the presence of the nitrogen bridgehead atom in 2 opens up new venues for interactions with protons, which allows the complex to act as a catalyst for proton reduction, a very rare property among cyanide bearing mimics of the $[2 \mathrm{Fe}]$ subsite. However, considering the high activity reported for 2 when inserted into the enzyme it is rather surprising that the first reduction process is shifted by at least $400 \mathrm{mV}$ towards more anodic potentials compared to its dicyanide analogue, $\mathbf{1}$. Truly this underscores the effect of the protein framework in tuning the electron donating capacity of the cyanide ligands.

Still, the catalytic capacity of 2 provides a first explanation as to why this complex, but not 3 , is capable of generating highly active artificial hydrogenases, and highlights the importance of the bridgehead nitrogen. Moreover, our capacity to selectively protonate either the cyanide ligand or the bridgehead nitrogen appears to result in two distinct mechanisms for proton reduction, which is currently under further investigation.

\section{Acknowledgements}

Dr Andreas Orthaber and Dr Edgar Mijangos at Uppsala University are gratefully acknowledged for their assistance in crystallography and electrochemistry experiments, respectively.

The Swedish Research Council, VR (contract no. 621-20145670), The Swedish Research Council for Environment, Agricultural Sciences and Spatial Planning, Formas (contract no. 213-2014-880), the foundation Kung Carl XVI Gustafs 50års-fond för vetenskap, miljö och teknik and the Wenner-Gren foundations are gratefully acknowledged for funding.

\section{Notes and references}

1 J. W. Peters, W. N. Lanzilotta, B. J. Lemon and L. C. Seefeldt, Science, 1998, 282, 1853-1858.

2 Y. Nicolet, A. L. de Lacey, X. Vernede, V. M. Fernandez, E. C. Hatchikian and J. C. Fontecilla-Camps, J. Am. Chem. Soc., 2001, 123, 1596-1601.

3 A. Silakov, B. Wenk, E. Reijerse and W. Lubitz, Phys. Chem. Chem. Phys., 2009, 11, 6592-6599.

4 G. Berggren, A. Adamska, C. Lambertz, T. R. Simmons, J. Esselborn, M. Atta, S. Gambarelli, J. M. Mouesca, E. Reijerse, W. Lubitz, T. Happe, V. Artero and M. Fontecave, Nature, 2013, 499, 66-69.

5 T. R. Simmons, G. Berggren, M. Bacchi, M. Fontecave and V. Artero, Coord. Chem. Rev., 2014, 270-271, 127-150.

6 C. Tard and C. J. Pickett, Chem. Rev., 2009, 109, 2245-2274.

7 M. Schmidt, S. M. Contakes and T. B. Rauchfuss, J. Am. Chem. Soc., 1999, 121, 9736-9737.

8 F. Gloaguen, J. D. Lawrence, M. Schmidt, S. R. Wilson and T. B. Rauchfuss, J. Am. Chem. Soc., 2001, 123, 12518-12527.

9 J. D. Lawrence, H. Li, T. B. Rauchfuss, M. Bénard and M.-M. Rohmer, Angew. Chem., Int. Ed., 2001, 40, 1768-1771.

10 F. Gloaguen, J. D. Lawrence and T. B. Rauchfuss, J. Am. Chem. Soc., 2001, 123, 9476-9477.

11 E. J. Lyon, I. P. Georgakaki, J. H. Reibenspies and M. Y. Darensbourg, Angew. Chem., Int. Ed., 1999, 38, 31783180 .

12 A. Le Cloirec, S. C. Davies, D. J. Evans, D. L. Hughes, C. J. Pickett, S. P. Best and S. Borg, Chem. Commun., 1999, 2285-2286.

13 J. A. Wright, L. Webster, A. Jablonskyte, P. M. Woi, S. K. Ibrahim and C. J. Pickett, Faraday Discuss., 2011, 148, 359-371.

14 H. Li and T. B. Rauchfuss, J. Am. Chem. Soc., 2002, 124, 726-727.

15 L.-C. Song, Z.-Y. Yang, H.-Z. Bian and Q.-M. Hu, Organometallics, 2004, 23, 3082-3084.

16 J. Esselborn, C. Lambertz, A. Adamska-Venkatesh, T. Simmons, G. Berggren, J. Noth, J. Siebel, A. Hemschemeier, V. Artero, E. Reijerse, M. Fontecave, W. Lubitz and T. Happe, Nat. Chem. Biol., 2013, 9, 607-609.

17 R. Gilbert-Wilson, J. F. Siebel, A. Adamska-Venkatesh, C. C. Pham, E. Reijerse, H. Wang, S. P. Cramer, W. Lubitz 
and T. B. Rauchfuss, J. Am. Chem. Soc., 2015, 137, 89989005.

18 J. F. Siebel, A. Adamska-Venkatesh, K. Weber, S. Rumpel, E. Reijerse and W. Lubitz, Biochemistry, 2015, 54, 14741483.

19 J. Esselborn, N. Muraki, K. Klein, V. Engelbrecht, N. Metzler-Nolte, U. P. Apfel, E. Hofmann, G. Kurisu and T. Happe, Chem. Sci., 2016, 7, 959-968.

20 A. Adamska-Venkatesh, S. Roy, J. F. Siebel, T. R. Simmons, M. Fontecave, V. Artero, E. Reijerse and W. Lubitz, J. Am. Chem. Soc., 2015, 137, 12744-12747.

21 G. M. Sheldrick, Acta Crystallogr., Sect. A: Fundam. Crystallogr., 2008, 64, 112-122.
22 A. Hemschemeier, A. Melis and T. Happe, Photosynth. Res., 2009, 102, 523-540.

23 K. A. Vincent, G. J. Tilley, N. C. Quammie, I. Streeter, B. K. Burgess, M. R. Cheesman and F. A. Armstrong, Chem. Commun., 2003, 2590-2591.

24 S. Roy, M. Bacchi, G. Berggren and V. Artero, ChemSusChem, 2015, 8, 3632-3638.

25 B. G. Cox, Acids and Bases - Solvent Effects on Acid-Base Strength, Oxford University Press, Oxford, 2013.

26 V. Fourmond, P.-A. Jacques, M. Fontecave and V. Artero, Inorg. Chem., 2010, 49, 10338-10347.

27 Z. Wang, J.-H. Liu, C.-J. He, S. Jiang, B. Åkermark and L.-C. Sun, J. Organomet. Chem., 2007, 692, 5501-5507. 